УДК 655.3.022

\title{
PHYSICAL PROCESSES OF AN IMPRINT CREATION IN OFFSET PRINTING
}

\author{
B. Kushlyk, O. Kushlyk-Dyvulska \\ National Technical University of Ukraine \\ "Igor Sikorsky Kyiv Polytechnic Institute” Ukraine \\ 37, Prosp. Peremohy, Kyiv, 03056, Ukraine
}

The mathematical model using the field theory had been used to correct the supply values of the printing ink to set the printing press up for the optimal ink transfer to the imprint. Determining the optimal values of controlling ink supply is figured to be more critical rather than controlling the dampening solution supply, through it availability to be supplied zonally and due to various printing elements area on the printing form. Modelling the process allows to forecast the use of cause-consequential ties in order to achieve the stability of the printing process from the printing machine setup through the print run to the printing finish.

Through the vector field with the means of integral calculus the ink transfer to the imprint had been researched. The ink layer thickness had been determined as the cylindrical surface height, with taking into the account its optimal maximal transfer to the printed surface. Gained equations are showcasing the growth of previously conducted research and allow the more exact understanding of the ink-transfer mechanism in the offset printing while utilizing the realistic environment of dampening solution zonal supply adjustment absence. Based on the divergence definition, and also based on the experimentally obtained data, the research of ink optical densities had been conducted, also the colour deviations were researched along the whole imprint's surface in dynamics.

Keywords: technological process, offset printing, vector field flow, raster point, integral calculus, surface integral, volume, test form, area.

\section{Introduction}

The use of offset printing [1] for low-run products is becoming a more well-known and widespread type of printing today as the number of orders for printing full-color brochures, booklets, stickers, magazines, replicas of leaflets, books, business cards, etc. is increasing.

The experimental studies carried out with their statistical analysis [2] led to the possibility of considering the transfer of paint to the printed material using a physical and mathematical apparatus, in particular, means of integral calculus using elements of field theory.

Certain objective things occurring on the print contact area are related to the design of the printing section. In [3], the change in the properties of the elements of the 
printing press during printing was studied, which allowed to establish a change in the microgeometry of the surface of the printing and gap elements. It is known that there is a possibility to zonally adjust the supply of ink, but there is no possibility (for the printing of small products) to regulate the wetting solution zonally, and in the end to comply with the requirements of the printing standard ISO 12647-2.

The process of forming an image, which is carried over by the offset blanket and is then transferred to the imprint, is the result of physical phenomena on the surface of the boundary of environments. The proper implementation of the offset printing process depends on many physical and chemical phenomena associated with the materials and components involved in it. The quality of the offset printing is influenced by: the printing form [4], the ink rollers, the rubber blanket, the properties of the printing ink, the dampening solution, the printing material, the design features of the printing press, the type and method of use of cleaning and washing solutions, relative humidity and air temperature in the printshop. Of great importance in the printing process is the properties interaction of the printed material and the technological process, as long as the change of components, and non-compliance to the set parameters leads to instability of the process, and causes defect production [5-7].

In [8], a model of the process of the dampening solution transfer between the rollers of the dampening apparatus was built, and a method for measuring the dampening solution on the rollers of the dampening apparatus was proposed, which allows controlling the uniformity of the solution layer for stabilizing the modes during the operation of the printing machine. On the basis of the analysis of the mutual influence of the parameters of the printing and gap elements of the printing forms, the composition of ink and dampening solution, the processes of technological solutions preparation [9], the newest aspects of the problem of wetting of printing forms in offset printing were established, in particular, the use of antibacterial additives was used to ensure the circulation stability of printing forms and environmental friendliness of printing manufacturing.

The monograph [11] proposes a mathematical model for solving the problem of finding optimal controls when choosing and correcting the supply of ink and dampening solution in the process of setting the printing machine to print and maintaining the normalized values of optical density and color deviations on the imprint in the printing process, with the "ink-water" balance, in which the parabolic form of the change trajectory in the amount of ink or dampening solution is determined by controlling "increase" or "decrease". On the basis of experimental studies, the working regime of a specific additive to the humidifying solution was determined and the main modes of work were modeled to support the balance of "ink-water".

The study showed the possibility of adjusting the process of achieving and maintaining the balance of "ink-water" with certain values and values of the supply of paint, a dampening solution, according to the number of printing and non-printing elements on the printed form. For a developed and improved test form, the ratio of the areas was 9:11, but the carried out experimental studies after results were processed showed the required ratio of 14:11. 


\section{Methods}

The purpose of the study is to apply mathematical methods for analyzing the physical processes of ink transfer as a result of the production of low-run printing products by offset printing, adjustment of the printing form in accordance with the generally accepted indicators of optical density.

\section{Results and discussions}

Because of the flow of a vector field, one can characterize a phenomenon such as the transfer of ink [12] from the printed form to the imprint. Accordingly, knowing the normative values of the area of the printing element on the printed form, the rate of dot gain, as well as the standard thickness of the ink layer, it is possible to accurately determine the amount of ink required to achieve optimal saturation at this point. Or, on the contrary, if there are any failures, clearly determine which of the items is causing the distortion.

Let's consider the well-known method of integral calculus for determining the vector field flow. Let [13] give a certain domain $V$ in space, in this area a surface $\sigma$, limited by the spatial line $L$ is given.

For a surface $\sigma$ at each point, a normal $\vec{n}=\cos \alpha \vec{i}+\cos \beta \vec{j}+\cos \gamma \vec{k},(|\vec{n}|=1)$ and vector function $\vec{F}=P(x ; y ; z) \vec{i}+Q(x ; y ; z) \vec{j}+R(x ; y ; z) \vec{k}$, is defined, that is, a vector field on the surface $\sigma$. We divide the surface $\sigma$ by arbitrary method on $n$ elementary parts $\Delta \sigma_{i}$, inside each part, take an arbitrary point $M_{i}\left(\xi_{i}, \eta_{i}, \zeta_{i}\right), i=1,2, \ldots n$. Compute the value of the function $\vec{F}_{i}=\vec{F}\left(M_{i}\right)$, the scalar product of the vectors $\vec{F}_{i}$ and $\vec{n}_{i}$, and make the sum

$$
\sum_{i=1}^{n} \vec{F}_{i} \vec{n}_{i} \Delta \sigma_{i}=\sum_{i=1}^{n}\left(\vec{F}\left(M_{i}\right) \cdot \vec{n}\left(M_{i}\right)\right) \Delta \sigma_{i} .
$$

The sum is integral, and its finite boundary, provided that each of the diameters of the elementary parts goes to zero, and the independence of the choice of points $M_{i} \in \Delta \sigma_{i}$, is called the surface integral of the second kind:

$$
\iint_{\sigma} \vec{F} \cdot \vec{n} d \sigma=\lim _{n \rightarrow \infty} \sum_{i=1}^{n}\left(\vec{F}\left(M_{i}\right) \cdot \vec{n}\left(M_{i}\right)\right) \Delta \sigma_{i} .
$$

By the rule of calculating the scalar product for the expression of the i-th clause we have

$$
\left(\vec{F}\left(M_{i}\right) \cdot \vec{n}\left(M_{i}\right)\right) \Delta \sigma_{i}=\left|\vec{F}_{i}\right| \cdot\left|\vec{n}_{i}\right| \cdot \cos \varphi \cdot \Delta \sigma_{i}=\left|\vec{F}_{i}\right| \cdot \cos \varphi \cdot \Delta \sigma_{i}
$$

The last expression defines the volume of the cylinder with the base $\Delta \sigma_{i}$ and height $\left|\vec{F}_{i}\right| \cos \varphi$. Consequently, when it is known that the vector field $\vec{F}$ is the velocity of a liquid flowing through the surface $\sigma$, then the product (1) is equal to the volume of fluid flowing through the plane $\Delta \sigma_{i}$ per unit time in the direction of the vector $\vec{F}_{i}$.

Thus, the expression $\iint_{\sigma} \vec{F} \cdot \vec{n} d \sigma$ represents the total amount of fluid flowing in a unit of time through the surface $\sigma$ and is the flow of a vector field $\vec{F}$ through the surface $\sigma$.

Consider the vector field $\vec{a}=x \vec{i}+y \vec{j}+z \vec{k}$ (the dot raster element is described by its position of space, that is, the radius vector), as the velocity of the fluid, which changes 
along with the change in the coordinates of the dot. We calculate its flow through the surface of a direct cylinder $S$ with a radius $R$ and the axis height of which coincides with the axis $O Z$, and the lower base lies in the plane $O X Y$. The cylinder's base can be interpreted as part of the plane area of the imprint on which the ink is transferred (printed material). Without loss of universality, consider the normal direction to the outside of the cylinder.

For the lateral surface of the cylinder $S_{1}$ equality is valid $\vec{a} \cdot \vec{n}_{1}^{0}=\Pi p_{\vec{n}_{1}^{0}} \vec{a}=R$. On the upper base of the cylinder $S_{2}$ we have $\vec{a} \cdot \vec{n}_{2}^{0}=\Pi p_{\vec{n}_{2}^{0}} \vec{a}=H$, and for $S_{3}$, as a lower base, $\vec{a} \cdot \vec{n}_{3}^{0}=0$.

In this case, we calculate the fluid flow according to the corresponding formula, as the sum of flows,

$$
\begin{gathered}
\Pi=\iint_{S} \vec{a} \cdot \vec{n}^{0} d S=\iint_{S_{1}} \vec{a} \cdot \vec{n}_{1}^{0} d S+\iint_{S_{2}} \vec{a} \cdot \vec{n}_{2}^{0} d S+\iint_{S_{3}} \vec{a} \cdot \vec{n}_{3}^{0} d S= \\
=\iint_{S_{1}} R d S+\iint_{S_{2}} H d S+\iint_{S_{3}} 0 d S=R \cdot 2 \pi R H+H \pi R^{2}=3 \pi R^{2} H .
\end{gathered}
$$

Also, according to the Ostrogradsky-Gauss formula, namely

get the same result, namely

$$
\Pi=\iint_{S} \vec{a} \cdot \vec{n}^{0} d S=\iiint_{V} \operatorname{div} \vec{a}(M) d x d y d z
$$

$$
\begin{gathered}
\operatorname{div} \vec{a}(M)=\frac{\partial P}{\partial x}+\frac{\partial Q}{\partial y}+\frac{\partial R}{\partial z}=1+1+1=3, \\
\Pi=\iint_{S} \vec{a} \cdot \vec{n}^{0} d S=\iiint_{V} 3 d x d y d z=3 V .
\end{gathered}
$$

Since the volume of the specified cylinder $V=\pi R^{2} H$, so

$$
\Pi=3 \pi R^{2} H \text {. }
$$

Consequently, if we put the Ostrogradsky-Gauss formula $P=x, Q=y, R=z$, we obtain an expression for calculating the volume of the area through an integral in its oriented in the positive direction of the external normal to the boundary of the region

$$
V=\frac{1}{3} \iint_{S} \vec{a} \cdot \vec{n}^{0} d S=\frac{1}{3} \iint_{s} x d y d z+y d x d z+z d x d y .
$$

On the other hand, let us consider the Ostrogradsky-Gauss formula for a plane case, in particular on a plane $X O Y$. Let in the general case a vector field $\vec{a}(M)=P(x, y) \vec{i}+Q(x, y) \vec{j}$, be given on a flat domain $G$, then the vector $\vec{n}$ is an external normal to a piecewise smooth contour $\Gamma$, that limits the specified regular smooth (lump-smooth) region $G$ in the plane. Fair formula

$$
\iint_{G}\left(\frac{\partial P}{\partial x}+\frac{\partial Q}{\partial y}\right) d x d y=\int_{\Gamma}(\vec{a} \cdot \vec{n}) d l
$$

where $d l$ - the arc differential.

Assuming that the direction of the tangent at each point coincides with the positive direction of the bypass of the curve, then

$$
\cos (n, x)=\cos (T, y)=\frac{d y}{d l}, \cos (n, y)=\cos (\pi-(T, x))=-\cos (T, x)=\frac{d x}{d l} .
$$


So $(\vec{a} \cdot \vec{n}) d l=P d y-Q d x$, which gives the formula

$$
\iint_{G}\left(\frac{\partial P}{\partial x}+\frac{\partial Q}{\partial y}\right) d x d y=\int_{\Gamma}(\vec{a} \cdot \vec{n}) d l=\int_{\Gamma} P d y-Q d x
$$

In this case, for transferring the ink to a plane, we have a circle of radius $R$, therefore

$$
\iint_{G}\left(\frac{\partial P}{\partial x}+\frac{\partial Q}{\partial y}\right) d x d y=2 S=2 \pi R^{2}
$$
For the second part of the formula, for computing $\int_{\Gamma} P d y-Q d x$, write a circle in a
parametric form

$$
\left\{\begin{array}{l}
x=R \cos t \\
y=R \sin t, 0 \leq t \leq 2 \pi
\end{array}\right.
$$

Then

$$
\int_{\Gamma} P d y-Q d x=\int_{0}^{2 \pi}(R \cos t \cdot R \cos t-R \sin t \cdot(-R \sin t)) d t=R^{2} \int_{0}^{2 \pi} d t=2 \pi R^{2} .
$$

Consequently, studies have shown that it is possible to determine the thickness of the ink layer, as the height of the cylindrical surface, taking into account its maximum transfer to the plane

$$
\Pi=3 \pi R^{2} H \approx 2 \pi R^{2} .
$$

The considered vector field $\vec{a}=x \vec{i}+y \vec{j}+z \vec{k}$ is potential, $\overrightarrow{\operatorname{rot}} a(M)=0$, it is a gradient of the scalar field. As is known, in the potential field, the work on moving the material point from the initial position to the finite, does not depend on the path of integration, but only on these points, that is, the difference in the potentials at these points.

The scalar field for this case, the gradient of which determines the vector field of motion of the raster point, has the form $u=1 / 2\left(x^{2}+y^{2}+z^{2}\right)$, which confirms the optimal transfer of the ink layer to a plane with a height of a cylindrical body close to the radius of the base.

Proceeding from the explanation of divergence as a scalar quantity (numerically equal to a density gradient), that is from a physical point of view a spatial change in the volume density of the vector flow, a study was conducted for the distribution of optical densities, values of color deviations across the width of the imprint in dynamics from the first and further through every 100 imprints (measurements were made and the correction of the ink supply by the automated control system was carried out on the basis of them).

For the values of measured optical density, its difference is characteristic when measuring in the lower and upper parts of the test image. At the same time, during the four iterations of the automated control system, it was not possible to stabilize the indicators at the level of the set value of 1.4 with a tolerance of \pm 0.05 units of standard. The graph of the dynamic change in optical density for each of the zones of the use of ink knives №№ 3-20 when measured at the bottom of the imprint is presented in fig. 1 . 


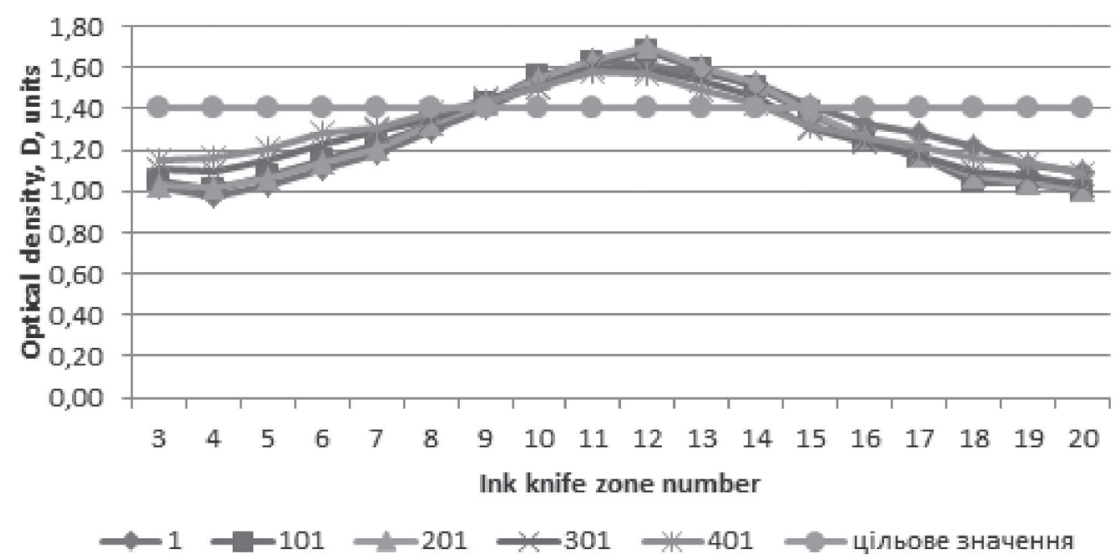

Fig. 1. Dynamics of changes in optical density during printing of a test copy.

Measurements taken at the imprint's bottom

In fig. 2. the graph of dynamical change in optical density for each of the zones of the use of paint knives №№ 3-20 is presented while the measurement taken at the top of the imprint.
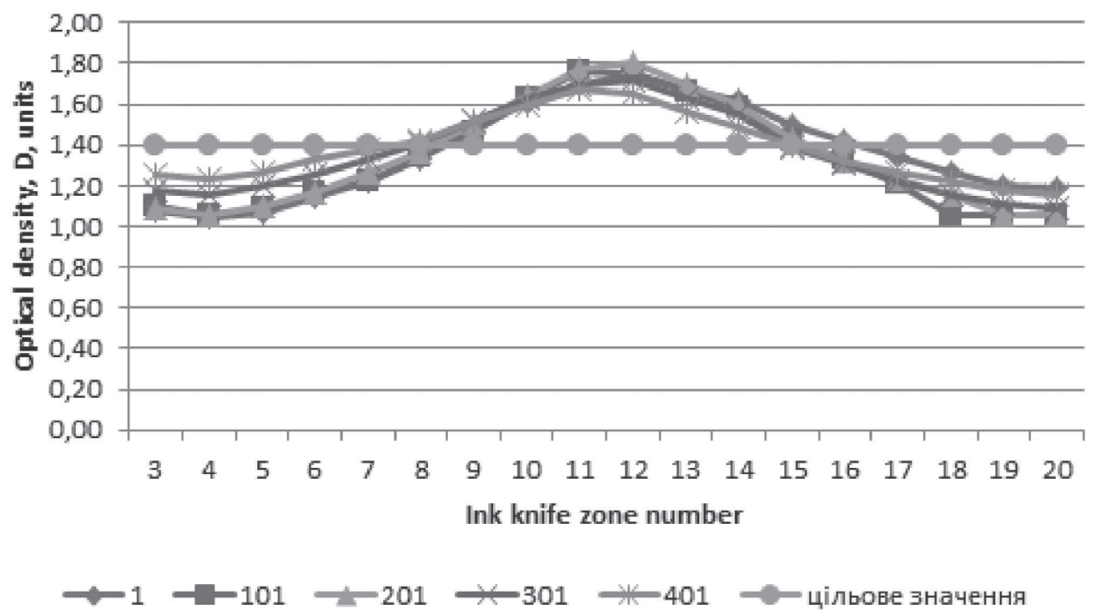

Fig. 2. Dynamics of change in optical density during the printing of a test copy.

Measurements are taken at the top of the test imprint

During the measurement, the value of the color deviations was marked by a distinct difference not only in the width of the print, which is clearly explained by the difference in optical densities and the difference in the inclination of the printing ink, but also in height at the area of action of one ink knife. The greatest difference in values could be observed in places where the solid printing element was changed to a gap element, which subsequently changed to the solid one back, fig 3,4 . 


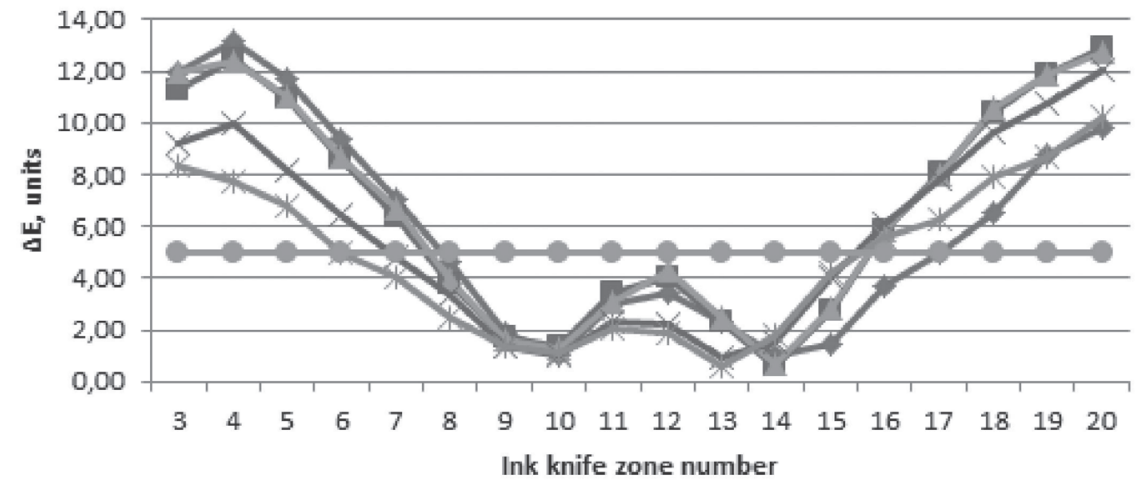

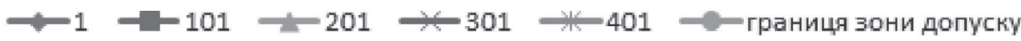

Fig. 3. Dynamical change of color deviation values during the test print. Measurements taken at the bottom of the imprint

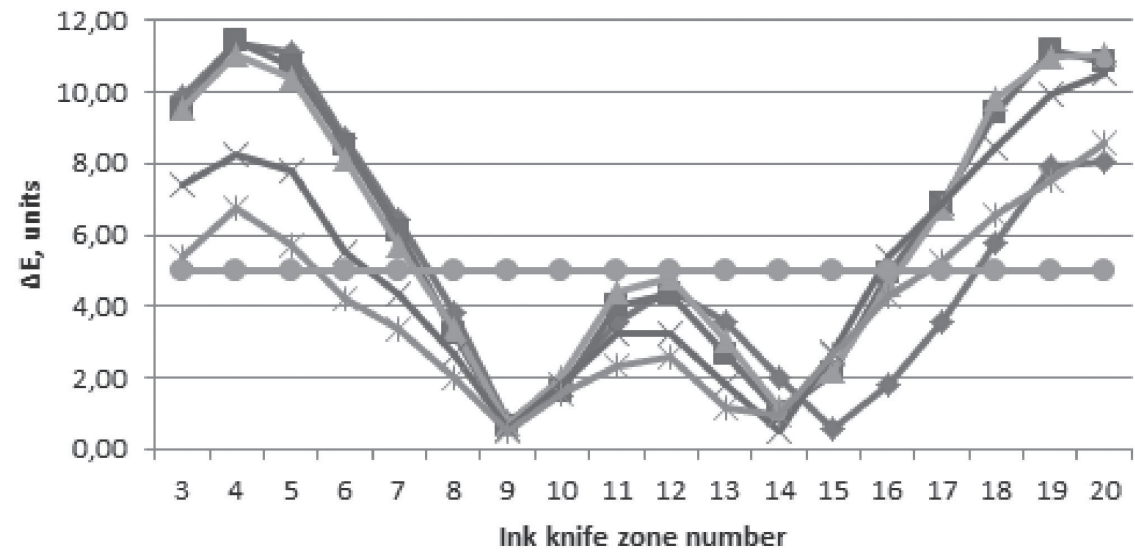

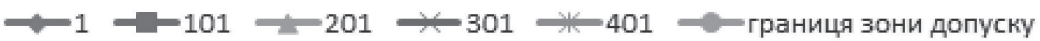

Fig. 4. Dynamical change of color deviation values during the test print. Measurements taken at the top of the imprint

While analyzing the trend, it is expected that after the fifth iteration, the imprint should be within the tolerance range, all subsequent iterations of the work would be only an adjustment character from the stabilization of the indicators to the given.

If analyzing the trend of the optical density stabilization, in places where the amount of ink exceeded the required target value, the four iterations made a much smaller change than in areas where the amount of ink was lower than the established ones. This testifies to the confirmation of mathematical reasons for the transfer of ink and gaining the set optical density in terms of elements of field theory. 


\section{Conclusions}

A mathematical model has been suggested for the problem of adjusting the ink supply in the process of setting the printing press to the printing, and then continuously optimally transmit the ink to the imprint.

\section{СПИСОК ВИКОРИСТАНИХ ДЖЕРЕЛ}

1. Сучасний стан технологій друкування в Україні / Савченко К. І., Зоренко О. В., Розум Т. В., Величко О. М. Технологія і техніка друкарства. 2011. № 2 (32). С. 21-27. URL: http://ttdrukvpi.kpi.ua/article/view/52761.

2. Кушлик Б. Р., Кушлик-Дивульська О. І. Принципи статистичного аналізу показників при аналізі якості відбитків плоского офсетного друку. Технологія і техніка друкарства. 2017. № 1 (55). C. 10-20. URL: http://ttdruk.vpi.kpi.ua/article/view/90686.

3. Скиба В. M. Printing stability of offset printing plates. Технологія і техніка друкарства. 2015. № 1 (47). С. 30-39. URL: http://ttdruk.vpi.kpi.ua/article/view/43272/39745.

4. Гавриш А. П., Зоренко О. В. Триботехнічний аналіз системи «друкарська форма-офсетне гумовотканинне полотнище-відбиток». Технологія і техніка друкарства. 2007. Вип. 3-4 (17-18). С. 36-40.

5. Зоренко Я. В. Технології репродукування плоским офсетним друком / за заг. ред. О. М. Величко. Київ : ВПЦ «Київський університет», 2015. 176 с.

6. Хохлова Р. А., Величко О. М. Оздоблення поліграфічної продукції лакуванням. Київ : ВПЦ «Київський університет», 2014. 183 с.

7. Золотухіна К. І., Величко О. М. Стабілізація параметрів відбитків у технологіях друкування на пористих і невсотувальних матеріалах / за заг. ред. О. М. Величко. Київ : ВПК «Політехніка», 2016. 160 с.

8. Углев А. В., Герценштейн И. Ш., Орлова Е. Ю. Способ измерения увлажняющего раствора на валиках пленочного увлажняющего апарата. Весник Московского государственного университета печати. 2015. № 1. C. 165-167. URL: http://cyberleninka. $\mathrm{ru} /$ article/n/sposob-izmereniya-uvlazhnyayuschego-rastvora-na-valikah-plenochnogo-uvlazhnyayuschego-apparata.

9. Величко О. М., Золотухіна К. І., Розум Т. В. Удосконалення процесів зволоження у офсетному друці. Технологія і техніка друкарства. 2016. № 2 (52). C. 4-12. URL: http:// ttdruk.vpi.kpi.ua/article/view/67886/pdf_20.

10. Velychko O., Zolotukhina K., Rozum T. The improvement of Dampening solution for offset printing. Eastern-European Journal of Enterprise Technologies. 2016. № 4. C. 37-43. URL: http://journals.uran.ua/eejet/article/view/74981.

11. Кушлик Б. Р., Кушлик-Дивульська О. І. Стабілізація друкування малотиражної продукції офсетним друком : монографія / за заг. ред. О. М. Величко. Київ : КПІ ім. Ігоря Сікорського, Вид-во «Політехніка», 2017. 162 с.

12. Regularities of ink-water balance stability in offset printing / Blagodir O., Zolotukhina K., Kushlyk B., Velychko O. EUREKA: Physics and Engineering. 2016. Issue 3. P. 31-37. doi: 10.21303/2461-4262.2016.00078. URL: http://eu-jr.eu/engineering/article/view/78/77.

13. Кушлик-Дивульська О. І. Вища математика. Елементи теорії поля і теорія рядів. Курс лекцій : навч. посіб. для студ. спеціальності 186 «Видавництво та поліграфія» / КПІ 
ім. Ігоря Сікорського ; уклад.: О. І. Кушлик-Дивульська, Н. В. Поліщук. Електронні текстові дані (1 файл: 3,12 МБ). Київ : КПІ ім. Ігоря Сікорського, 2018. 155 с. Назва 3 екрана. URL: http://ela.kpi.ua/handle/123456789/21729.

\section{REFERENCES}

1. Savchenko, K. I., Zorenko, O. V., Rozum, T. V., \& Velychko, O. M. (2011). Suchasnyi stan tekhnolohii drukuvannia v Ukraini: Tekhnolohiia i tekhnika drukarstva, 2 (32), 21-27. Retrieved from http://ttdrukvpi.kpi.ua/article/view/52761 (in Ukrainian).

2. Kushlyk, B. R., \& Kushlyk-Dyvulska, O. I. (2017). Pryntsypy statystychnoho analizu pokaznykiv pry analizi yakosti vidbytkiv ploskoho ofsetnoho druku: Tekhnolohiia i tekhnika drukarstva, 1 (55), 10-20. Retrieved from http://ttdruk.vpi.kpi.ua/article/view/ 90686 (in Ukrainian).

3. Skyba, V. M. (2015). Printing stability of offset printing plates: Tekhnolohiia i tekhnika drukarstva, 1 (47), 30-39. Retrieved from http://ttdruk.vpi.kpi.ua/article/view/43272/ 39745 (in Ukrainian).

4. Havrysh, A. P., \& Zorenko, O. V. (2007). Trybotekhnichnyi analiz systemy «drukarska forma-ofsetne humovotkanynne polotnyshche-vidbytok»: Tekhnolohiia i tekhnika drukarstva, 3-4 (17-18), 36-40 (in Ukrainian).

5. Zorenko, Ya. V. (2015). Tekhnolohii reprodukuvannia ploskym ofsetnym drukom / za zah. red. O. M. Velychko. Kyiv : VPTs «Kyivskyi universytet» (in Ukrainian).

6. Khokhlova, R. A., \& Velychko, O. M. (2014). Ozdoblennia polihrafichnoi produktsii lakuvanniam. Kyiv : VPTs «Kyivskyi universytet» (in Ukrainian).

7. Zolotukhina, K. I., \& Velychko, O. M. (2016). Stabilizatsiia parametriv vidbytkiv u tekhnolohiiakh drukuvannia na porystykh i nevsotuvalnykh materialakh / za zah. red. O. M. Velychko. Kyiv : VPK «Politekhnika» (in Ukrainian).

8. Uglev, A. V., Gertcenshtein, I. Sh., \& Orlova, E. Iu. (2015). Sposob izmereniia uvlazhniaiushchego rastvora na valikakh plenochnogo uvlazhniaiushchego aparata: Vesnik Moskovskogo gosudarstvennogo universiteta pechati, 1, 165-167. Retrieved from http:// cyberleninka.ru/article/n/sposob-izmereniya-uvlazhnyayuschego-rastvora-na-valikahplenochnogo-uvlazhnyayuschego-apparata (in Russian).

9. Velychko, O. M., Zolotukhina, K. I., \& Rozum, T. V. (2016). Udoskonalennia protsesiv zvolozhennia u ofsetnomu drutsi: Tekhnolohiia i tekhnika drukarstva, 2 (52), 4-12. Retrieved from http://ttdruk.vpi.kpi.ua/article/view/67886/pdf_20 (in Ukrainian).

10. Velychko, O., Zolotukhina, K., \& Rozum, T. (2016). The improvement of Dampening solution for offset printing: Eastern-European Journal of Enterprise Technologies, 4, 37-43 Retrieved from http://journals.uran.ua/eejet/article/view/74981 (in English).

11. Kushlyk, B. R., \& Kushlyk-Dyvulska, O. I. (2017). Stabilizatsiia drukuvannia malotyrazhnoi produktsii ofsetnym drukom / za zah. red. O. M. Velychko. Kyiv : KPI im. Ihoria Sikorskoho, Vyd-vo «Politekhnika» (in Ukrainian).

12. Blagodir, O., Zolotukhina, K., Kushlyk, B., \& Velychko, O. (2016). Regularities of ink-water balance stability in offset printing: EUREKA: Physics and Engineering, 3, 31-37. doi: 10.21303/2461-4262.2016.00078. Retrieved from http://eu-jr.eu/engineering/article/view/ 78/77 (in English). 
13. Kushlyk-Dyvulska, O. I. (2018). Vyshcha matematyka. Elementy teorii polia i teoriia riadiv. Kurs lektsii / KPI im. Ihoria Sikorskoho ; uklad.: O. I. Kushlyk-Dyvulska, N. V. Polishchuk. Elektronni tekstovi dani (1 fail: 3,12 MB). Kyiv : KPI im. Ihoria Sikorskoho. Nazva z ekrana. Retrieved from http://ela.kpi.ua/handle/123456789/21729 (in Ukrainian).

doi: 10.32403/0554-4866-2019-1-77-39-48

\title{
ФІЗИЧНІ ПРОЦЕСИ ПРИ ФОРМУВАННІ ВІДБИТКА В ПЛОСКОМУ ОФСЕТНОМУ ДРУЦІ
}

\author{
Б. Р. Кушлик, О. І. Кушлик-Дивульська \\ Національний технічний університет України \\ «Київський політехнічний інститут імені Ігоря Сікорського», \\ пр. Перемоги, 37, Київ, 03056, Україна \\ bodo_kush@hotmail.com,olgakushlyk64@gmail.com
}

Побудовано математичну модель з використанням елементів теорії поля корегування подачі фарбового розчину для налаштування друкарської машини до друку та оптимальності ї̈ передачі на відбиток. Визначення оптимальних величин керування подачею друкарської фарби визначено більи критичним, ніж керування зволожувальним розчином через наявність зонального впливу на ї̈ подачу та різну площу друкувальних елементів на друкарській формі. Моделювання проиесу дозволяє передбачити використання причинно-наслідкових зв'язків задля досягнення стабільності процесу друкування від початку прилагоджування машини до друку до завершення процесу друку протягом всього накладу.

Через потік векторного поля засобами інтегрального числення досліджено перенесення фарби із друкарської форми на відбиток. Визначено товщину фарбового шару, як висоту циліндричної поверхні, з урахуванням ї̈ оптимального максимального перенесення на площину. Отримані залежності розширюють раніше проведені дослідження та дозволяють точніме зрозуміти характер фарбоперенесення у плоскому офсетному друці за реальних умов при відсутності можливості керування зональною подачею зволожувального розчину. Виходячи із поняття дивергениії, на основі експериментальних даних, проведено дослідження розподілу оптичних густин, значень колірних відмінностей по всій ширині відбитка в динамічі.

Ключові слова: технологічний прочес, офсетний друк, потік векторного поля, растрова точка, інтегральне числення, поверхневий інтеграл, об'єм, тестова форма, площуа. 